\title{
Penguatan Nilai-Nilai Kearifan Lokal dalam Mengembangkan Kehidupan Sosial Religius Masyarakat di Desa Beririjarak
}

\author{
Baiq Yayuk Samsiniwati ${ }^{1}$, NikmatulJannah ${ }^{2}$, Ratna Sri Dewi ${ }^{3}$, Muhammad Yamin ${ }^{4}$, \\ RokyanZarkashi ${ }^{5}$, Muh.Mawardi ${ }^{6}$ Ahamad Tarmizi ${ }^{7}$ \\ ${ }^{1}$ Program Manajemen Pendidikan Islam, STAI Darul Kamal NW Kembang Kerang \\ ${ }^{2}$ Program Pendidikan Guru Madrasah Ibtidaiyah, STAI Darul Kamal NW Kembang Kerang \\ ${ }^{3}$ Program Manajemen Pendidikan Islam, STAI Darul Kamal NW Kembang Kerang \\ ${ }^{4}$ Program Studi Ilmu Al Qur'an dan Tafsir, STAI Darul Kamal NW Kembang Kerang \\ ${ }^{5}$ Program Studi Ilmu Al Qur'an dan Tafsir, STAI Darul Kamal NW Kembang Kerang \\ ${ }^{6}$ Program Pendidikan Guru Madrasah Ibtidaiyah, STAI Darul Kamal NW Kembang Kerang \\ ${ }^{7}$ Dosen STAI Darul Kamal NW Kembang Kerang \\ *e-mail: yayukbaiq16@gmail.com¹, nikmatuljannah1999@gmail.com² ${ }^{2}$ dewiratna199919@gmail.com³, \\ muhammadyamim88@gmail.com4, zrokyan@gmail.com5
}

\begin{abstract}
Dalam perspektif sosiologis, sebuah komunitas kehidupan masyarakat apapun dan dalam sope sekecil apapun memiliki sebuah nilai-nilai dan budaya yang telah mengakar sejalan dengan tumbuh dan berkembangnya komunitas tersebut sebagai acuan kehidupan. Begitu juga dengan keseharian masyarakat di Dusun Senganton Desa Beririjarak Kecamatan Wanasaba Kabupaten Lombok Timur syarat dengan nilai dan budaya lokal. Kegiatan ini bertujuan untuk mengingatkan kembali generasi muda tentang nilai-nilai kearifan lokal yang sangat berperan dalam menguatkan kehidupan sosial religius masyarakat setempat. Kegiatan ini dilaksanakan dengan pendekatan sosialisasi dan metode ceramah serta diskusi. Peserta kegiatan ini adalah para pemuda dan masyarakat setempat. Hasilnya adalah sebagian masyarakat baru menyadari adanya nilai-nilai kearifan lokal meskipun dalam keseharian mereka praktikkan antara lain: Tradisi upacara mitoni, yaitu tradisi yang memiliki berbagai nilai yang dapat dijadikan sumber pembelajaran. Tradisi Tahlilan (Selametan bagi orang yang meninggal dunia), yaitu tradisi yang memiliki berbagai nilai yang dapat dijadikan sumber pembelajaran. Nilai-nilai tersebut terdiri dari nilai sedekah, ukhwah islamiyah, tolong menolong, solidaritas, akidah, syariah, dan akhlak.
\end{abstract}

Keywords: Kearifan Lokal, Budaya, Sosial dan Religius

\footnotetext{
${ }^{1}$ STAI Darul Kamal NW Kembang Kerang

${ }^{2}$ STAI Darul Kamal NW Kembang Kerang

${ }^{3}$ STAI Darul Kamal NW Kembang Kerang

${ }^{4}$ STAI Darul Kamal NW Kembang Kerang

${ }^{5}$ STAI Darul Kamal NW Kembang Kerang

${ }^{6}$ STAI Darul Kamal NW Kembang Kerang

${ }^{7}$ STAI Darul Kamal NW Kembang Kerang
} 


\section{PENDAHULUAN}

Kegiatan Pengabdian ini bertujuan untuk mengingatkan kembali generasi muda tentang nilai-nilai kearifan lokal yang sangat berperan dalam menguatkan kehidupan sosial religius masyarakat. Dengan memilih lokasi di Dusun Senganton Desa Beririjarak Kecamatan Wanasaba Kabupaten Lombok Timur-NTB. Pilihan lokasi ini relevan karena Dusun Senganton ini mempunyai kebudayaan yang masih kental, semanagat gotong royong dan kekompakan menjadi satu hal yang selalu di junjung tinggi. Budaya-budaya di Dusun Senganton secara turun-temurun masih dipertahankan sampai sekarang ini. Situasi sosial kultural masyarakat Dusun Senganton desa beririjarak dapat dilihat dari kebiasaan (adat), baik yang berkaitan dengan ritual keagamaan maupun tradisi lokal dari masyarakat tersebut. Dusun Senganton mempunyai jumlah penduduk sebanyak 224 jiwa dengan penduduk usia produktif sebayak 39 jiwa, sedangkan penduduk yang dikategorikan miskin berjumlah 45 jiwa. Masyarakat dusun Senganton mempunyai mata pencaharian yang beragam, ada yang menjadi petani, baik petani sendiri maupun buruh tani, buruh bangunan, pedagang, peternak,dan banyak juga pergi kerja ke luar negeri seperti Malaysia dan lain sebagainya. Letak Geografis, Dusun Senganton ini berada pada areal persawahan dan perkebunan dengan kondisi tanah subur. Sebagian besar penduduk memanfaatkan lahan desa sebagai lahan pertanian dan perkebunan. Lahan tersebut menghasilkan dua sampai tiga kali panen dan beberapa penghasil buah-buahan. Selain itu penduduk juga menanam cabai dan tomat yang dipanen setiap bulan Agustus dan September.

Latar belakang melakukan kegiatan tentang sosialisasi nilai-nilai kearifan lokal karena melihat berkembangnya arus globalisasi secara nyata telah menggeser nilai-nilai budaya lokal asli Indonesia. Nilai budaya Asing yang berkembang begitu pesat di dalam kehidupan masyarakat sehingga berdampak luas pada keseimbangan lingkungan. Modernisasi kalau tidak disikapi secara kritis, dengan berbagai daya tarik dan propagandanya memang dapat membius seseorang sehingga lupa pada identitas dan jati dirinya sebagai Bangsa Indonesia. Ujung-ujungnya adalah makin terkikisnya nilai-nilai luhur budaya lokal, regonal maupun nasional. Mendewa-dewakan dan sikap membabi buta terhadap hal-hal yang berbau modern justru akan dapat merugikan bagi eksistensi budaya suatu bangsa itu sendiri.

Sebagian dari kehidupan masyarakat masih kokoh mempertahankan tradisi, berbeda dengan masyarakat yang mengalami pergeseran nilai-nilai. Realita pergeseran nilai-nilai budaya, mengakibatkan nilai-nilai budaya lokal terlupakan. Adat istiadat dan tata nilai yang ada dalam suatu masyarakat merupakan basis dalam mengatur tata perikelakuan anggota masyarakat. Rasanya akan banyak kehilangan sesuatu yang berharga apabila kekayaan adat istiatat dan budaya yang ada di kawasan Nusantara tidak dipelihara dan dikembangkan. Untuk itu perlu upaya penggalian terhadap apa yang disebut dengan istilah nilai-nilai kearifan lokal.

Pada hakikatnya budaya memiliki nilai-nilai yang senantiasa diwariskan dan dilaksanakan seiring dengan proses perubahan sosial kemasyarakatan. Pelaksanaan nilai- nilai budaya merupakan manifestasi dan legitimasi masyarakat terhadap budaya. Eksistensi budaya dan keragaman nilai-nilai luhur kebudayaan yang dimiliki oleh bangsa Indonesia merupakan sarana dalam membangun karakter warga negara. Konsepsi di atas menunjukkan 
bahwa betapa pentingnya budaya dan nilai-nilai yang terkandung dalam budaya sebagai pondasi dalam pembangunan karakter bangsa. ${ }^{8}$

Namun seiring perkembangan zaman, eksistensi budaya dan nilai-nilai budaya yang dimiliki oleh Bangsa Indonesia sampai saat ini belum optimal dalam upaya membangun karakter warga negara, fenomena sosial yang muncul akhir-akhir ini cukup mengkhawatirkan, fenomena kekerasan dalam menyelesaikan masalah, meningkatnya perilaku merusak diri, seperti narkoba, alkohol dan seks bebas, menurunnya perilaku sopan santun, menurunnya perilaku kejujuran, menurunnya rasa kebersamaan, dan menurunnya rasa gotong royong di antara anggota masyarakat. Berkaitan dengan hal tersebut Syam mengungkapkan bahwa perilaku keras, beringas, korupsi, keterpurukan ekonomi yang berkelanjutan adalah pertanda kekalahan budaya. Karakter Bangsa dibentuk oleh kreativitas bangsa itu sendiri. Kreativitas akan berkaitan erat dengan kesejahteraan, maka perlu rujukan budaya tradisi yang bernilai dinamis dan positif yang memang terdapat pada semua subkultur bangsa ini. ${ }^{9}$

Pendapat Syam di atas memberi petunjuk bahwa negara yang mampu menjaga dan melestarikan nilai-nilai budaya dapat berkembang dengan baik dan mampu meminimalisir penyakit-penyakit sosial masyarakat. Di era globalisasi sekarang ini, seluruh aspek kehidupan yang serba terbuka tanpa terkendali dan kurangnya filterisasi serta kondisi masyarakat yang belum siap mengakibatkan masyarakat Indonesia terbawa arus kebebasan yang lebih berorientasi pada individualisme dan materialisme serta mulai melupakan kegiatan-kegiatan gotong royong yang terdapat dalam budaya lokal.

\section{METODE}

Kegiatan ini dilakukan dengan pendekatan sosialisasi dan menggunakan metode ceramah serta diskusi. Pelaksanaan pengabdian pada masyarakat ini bekerjasama dengan Kepala Desa dan Kepala Dusun Senganton.Peserta kegiatan ini adalah para pemuda dan masyarakat setempat di Dusun Senganton Desa Beririjarak.Adapun tahapan pelaksanaan pengabdian ini terdiri dari:

1. Tahap persiapan, yaitu studi lapangan dengan melakukan: a) survey pendahuluan; b) menentukan kelayakan sasaran; c) mengidentifikasi beberapa pihak sebagai pendukung kegiatan.

2. Tahap pelaksanaan, yaitu melaksanakan sosialisasi atau ceramah berupa penyajian materi sosialisasi/FGD dan ikut pertisipasi dalam melestarikan budaya lokal yang ada

${ }^{8}$ Karakter bangsa dibangun bukan berdasarkan pada formula yang instan dan kondisi yang instan pula, melainkan dibangun berdasarkan kebutuhan masyarakat dengan memperhatikan aktivitas masyarakat yang terbina secara turun temurun. Dan itu bisa diperoleh apabila kita memperhatikan keragaman budaya dan nilai- nilai budaya yang dimiliki oleh bangsa ini. Lihat Yunus, Rasid, Nilai-nilai Kearifan Lokal (Local Genius) sebagai Penguat Karakter Bangsa: Studi Empiris tentang Huyula, (Yogyakarta: Deepublish, 2014), hal.1

9. Syam, F, Renungan BJ. Habibie Membangun Peradaban Indonesia, (Jakarta: Gema Insani, 2009), hal. 285-286. 
3. Tahap evaluasi, yaitu penilaian terhadap: a) Kehadiran Para pemuda dan masyarakat sejak awal hingga akhir kegiatan sosialisasi. b) Keaktifan dalam diskusi/bertanya. Instrumen yang digunakan adalah berupa dokumentasi photo atau video dan catatan secara anekdot terhadap partisipasi para pemuda dan masyarkat dalam diskusi

\section{HASIL DAN PEMBAHASAN $\leftarrow$ Ebrima, Bold, $11 \mathrm{pt}$}

Pengabdian kepada masyarakat adalah usaha untuk menyebarluaskan ilmu pengetahuan, teknologi, dan seni kepada masyarakat. Kegiatan tersebut harus mampu memberikan suatu nilai tambah bagi masyarakat, baik dalam kegiatan ekonomi, kebijakan, dan perubahan perilaku (sosial). Uraikan bahwa kegiatan pengabdian telah mampu memberi perubahan bagi individu/masyarakat maupun institusi baik jangka pendek maupun jangka panjang.

\section{A. Profil Sosial Budaya Masyarakat}

\section{Dusun Senganton Desa Beririjarak}

Desa Beririjarak merupakan desa yang terletak di Kecamatan Wanasaba Kabupaten Lombok Timur, Provinsi Nusa Tenggara Barat. Terletak di bagian barat Kecamatan Wanasaba berbatasan langsung dengan TNGR( Taman Nasional Gunung Rinjani) di sebelah utara, Desa Bebidas dan Desa Jinang di sebelah timur Desa Karang Baru di sebelah selatan dan Desa Kembang Kerang di sebelah barat. Pusat pemerintahan Desa Beririjarak berada di jalan kebun produksi No 1 dengan jarak tempuh menuju pusat pemerintahan kecamatan -+ $3 \mathrm{~km}$ dan $22 \mathrm{~km}$ menuju provinsi. ${ }^{10}$

Desa Beririjarak memiliki 9 dusun yaitu: Dusun beririjarak selatan, Dusun Otak Kebun, Dusun Senganton, Dusun Ambangan, Beririjarak Utara, Beririjarak Timur, Ambangan timur, dan Otak Kebun Timur. Desa Beririjarak semenjak ditetapkan menjadi desa definitif, Desa Beririjarak terus melakukan pembenahan disegala bidang menuju desa religius, berbudaya dan mandiri untuk mensejajarkan diri dengan desa-desa lain di Kabupaten Lombok Timur yakni dengan moto "Bersatu Dalam Perbedaan Dan Berbeda Dalam Persatuan ${ }^{\prime 11}$

Masyarakat Desa Beririjarak tidak terlepas dari kehidupan sosial budaya yang ada. Artinya semakin maju budaya suatu daerah memungkinkan terjadinya perlabuhan-

${ }^{10}$ Lihat Dokumen Desa Beririjarak tentang profil Desa.

${ }^{11}$ Hasil diskusi bersama Kepala Desa (18 Pebruari 2021), Lihat Juga Dokumen Desa Beririjarak 
perlabuhan ke arah yang lebih baik, dalam arti yang sederhana maju dan berkembangnya suatu masyarakat sangat dipengaruhi oleh peradaban dan kebudayaan-kebudayaan yang ada di dalamnya. ${ }^{12}$ Keanekaragaman budaya dan kehidupan sosial juga dipegaruhi oleh karakteristik dan perilaku serta pola pikir suatu masyarakat. Artinya suatu masyarakat dipandang memiliki budaya dan nilai sosial yang tinggi tergantung pada cara pandang dan bagaimana cara menyikapinya, sehingga kebudayaan apapun yang datang dapat diseleksi dengan baik dan pada gilirannya mendapat posisi dalam ruang dan waktu dalam suatu masyarakat. ${ }^{13}$

Adapun bentuk kehidupan sosial budaya yang ada dimasyarakat Desa Beririjarak dapat diidentifikasi melalui kebudayaan yang ada antara lain: ${ }^{14}$

1. Adat istiadat yang masih dilaksanakan, adat istiadat yang masih terlihat dan sering dilaksanakan oleh masyarakat beririjarak masih diwarnai oleh kebiasaan-kebiasaan (kebudayaan) yang diwarisi oleh nenek moyang yang diwarisi oleh nenek suku sasak karena hampir sebagian masyarakatnya berasal dari suku sasak. Adat istiadat yang dimaksud misalnya: prosesi perkawinan selalu di rangkaikan dengan adat sasak (begawe), namun tidak keluar dari nilai-nilai sosial dan kebudayaan.

2. Kesenian menjadi kesukaan dam perkembangannya, adapun keseniaan yang masih digemari oleh masyarakarat desa beririjarak adalah ngaji kayat dan selakaran, serta kesenian-kesenian religius seperti nasid dan lain sebagainya. Kesenian yang masih dikembangkan sampai sekarang memiliki kontribusi yang positif disamping sebagai pelestarian budaya juga sebagai mendidik dan menggali potensi sumber daya manusia yang ada. Selain hal itu, kesenian-kesenian itu juga sebagai latihan vocal dan hiburan.

${ }^{12}$ Desa Beririjarak mempunyai jumlah penduduk sebanyak 3290 jiwa dengan penduduk usia produktif 1312 jiwa, sedangkan penduduk yang dikategorikan miskin 1025 jiwa. Mata pencaharian sebagian penduduk adalah petani sedangkan hasil produksi ekonomis desa yang menonjol adalah padi, cabai Besar, dan Tomat. Hasil Wawancara bersama Kepala Desa Beririjarak (18 Perbruari 2021)

13 Hasil Diskusi Bersama Muh. Tarmizi Tahir Selaku Pembimbing Lapangan (18 Pebruari 2021)

${ }^{14}$ Hasil diskusi bersama Kepala Desa (18 Pebruari 2021), Lihat Juga Dokumen Desa Beririjarak 
3. Pendidikan sekolah yang ada pada suatu masyarakat dapat dilihat tingkat kemajuannya dengan melihat pendididkan yang ada. Karena pendidikan merupakan salah satu asas penting untuk memajukan dam mewujudkan suatu masyarakat yang religius, intelektual dan mampu bersaing dengan kemajuan IPTEK harus pendapat prioritas dan perhatian yang serius dari berbagai pihak. Sedangkan pada Desa Beririjarak lembaga-lembaga pendidikan yang dapat dideteksi antara lain: mulai dari tingkat pendidikan Anak Usia Dini (PAUD), TK, MI,SD, SMP, MTsN3 Lombok Timur dan MAN 2 Lombok Timur.

Desa beririjarak secara keseluruhan memeluk agama Islam, jadi bisa dikatakatan bahwa tidak pernah terjadi kasus perselisihan antara umat beragama di desa beririjarak ini. Diwilayah desa Beririjarak terdapat beberapa masjid dan musolla yang sering digunakan masyarakat setempat dalam beribadah, seperi untuk sholat, ngaji, dan acara keagamaan lainnya. Selain itu juga disetiap dusun mempunyai tokoh agama yang sangat dihormati, memiliki masjid dan musolla sendiri dan memiliki Kiyai masing-masing. ${ }^{15}$

\section{B. Sosialisasi Nilai-Nilai Kearifan Lokal di Dusun Senganton}

Hasil pemikiran, cipta dan karya manusia merupakan kebudayaan yang berkembang pada masyarakat, pikiran dan perbuatan yang dilakukan oleh manusia secara

${ }^{15}$ Kyai yang dimaksud disini bukanlah harus orang- orang yang sudah naik haji atau ustadz, akan tetapi orang yang merupakan orang yang dipercaya oleh warga setempat yang setidaknya memiliki pemahaman tentang agama, Kyai disini bisa juga merupakan sesepuh di dusun tersebut. Meskipun begitu posisi Kyai disini tidak kalah penting dari pelaksana kewilayahan suarau dusun, karena biasaya dalam segala pengambilan keputusan yang berkaitan dengan kepentingan masyarakat banyak. Selalu dimusyawarahkan terlebih dahulu dengan pak Kyai, jadi seorang Kyai disini sangatlah penting keberadaannya. Untuk kegiatan agama sendiri yang rutin dilakukan oleh warga Desa Beririjarak secara umum yakni, yasinan, hiziban, brazanjian, pengajian umum di masjid dan musolla. Dan juga perayaan hari besar islam lainnya. Hasil Wawancara bersama Kepala Desa (18 Pebruari 2021), Lihat Juga Dokumen Desa Beririjarak 
terusmenerus pada akhirnya menjadi sebuah tradisi. ${ }^{16}$ Kegiatan pengabdian kepada masyarakat ini dilaksanakan dalam bentuk sosialisasi. Sesuai dengan dokumentasi berupa photo atau video, catatan dan pantauan, para pemuda dan masyarakat hadir sejak awal hingga akhir kegiatan sosialisasi. Teridentifikasi para pemuda dan masyarakat berpartisipasi aktif selama kegiatan sosiaisasi. Hal ini mencerminkan kegiatan sosialisasi berjalan dengan baik.

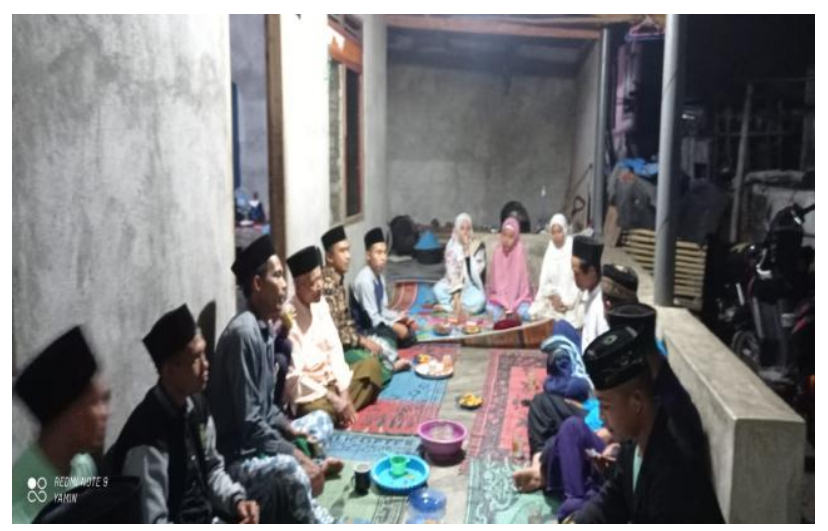

Kegiatan sosialisasi dan diskusi tentang nilai-nilai kearifan lokal dilakukan di dalam masjid setiap selesai shalat lima waktu. Sosialisasi dan diskusi dapat menyadarkan para pemuda dan masyarakat Dusun Senganton ternyata di dalam budaya-budaya yang dilestarikan terdapat nilai-nilai religius kemanusiaan. Di antara Tradisi-tradisi yang masih dilestarikan dan dikembangkan di Dusun Senganton, Sebagaimana di jelaskan oleh Kepala Dusun dan Tokoh Masyarakat sebagai berikut

\section{Ucapara mitoni}

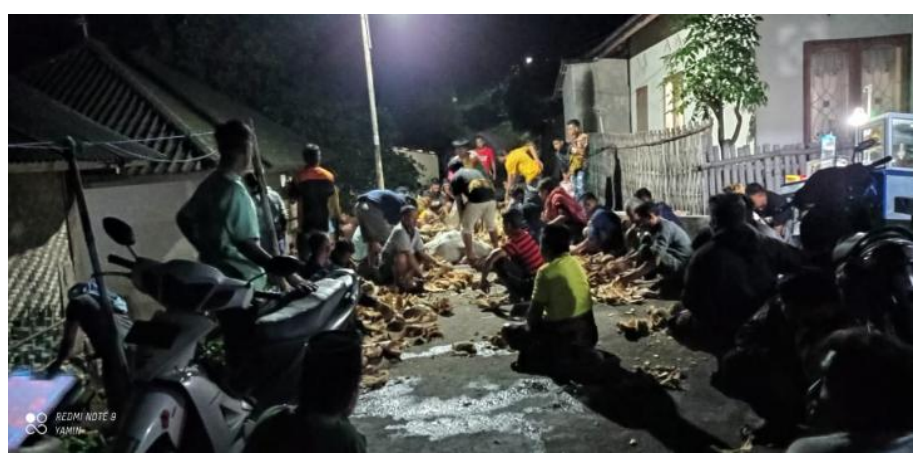

Upacara ini diselenggarakan untuk memperingati usia khamilan yang sudah menginjak 7 bulan, dengan harapan si cabang bayi mendapatkan berkah dari allah

${ }^{16}$ Tradisi merupakan proses situasi kemasyarakatan yang di dalamnya unsur-unsur dari warisan kebudayaan dan dipindahkan dari generasi ke generasi. Koentjaraningrat, "Pengantar Ilmu Antropologi," (Jakarta: Rineka Cipta, 2000), 332. Lihat juga Thomas Dawes Elliot and Henry Pratt Fair Child, Dictionary of Sociology and Related Sciences, New Jersey: Little Field, Adam\& Co, 1975, 322. 
SWT, menjadi anak yang soleh solehah berguna bagi nusa dan bangsa serta agamanya dan juga berbakti kepada orang tuanya. Mitoni ${ }^{17}$, pada intinya merupakan acara selametan. Tradisi ini dilakukan pada saat kandungan anak pertama memasuki usia tujuh bulan. Dalam sosialisasi dan diskusi masyarakat Dusun Senganton dengan khidmat memperhatikan dan merespon materi yang di sampaikan, sebagian masyarakat belum menyadari bahwa tradisi-tradisi yang selama ini dikembangkan khususnya tradisi upacara mitoni mempunyai nilai-nilai yang dapat dijadikan sebagai penguatan dalam melakukan kehidupan sosial. Dalam tradisi mitoni ini ada beberapa nilai-nilai yang terkandung untuk dijadikan penguatan dalam mengembangkan kehidupan sosial kemasyarakatan yang religius dan diwariskan kepada generasi muda di antara:nilai-nilai religi (spiritual), pendidikan, menjaga psikologis dan kesehatan serta hubungan sosial kemasyarakatan.

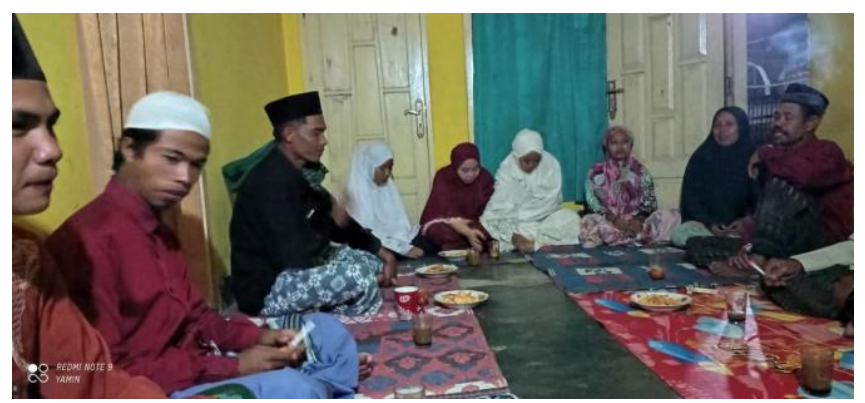

Dalam kegiatan sosialisasi/ceramah dan diskusi kami menjelaskan satu persatu kepada pemuda dan masyarakat tentang nilai-nilai yang ada dalam tradisi upacara mitoni tersebut. Pertama, Nilai Religius dan Pendidikan, yaitu dari serangkian acara ritual upacara mitoni yang bapak ibu lakukan, mulai dari pembecaan ayat-ayat al-Qur'an pada surahsurah tertentu sampai mendo'akan cabang bayi semoga menjadi anak yang sholeh sholehah itu merupakan bagian dari ajaran Tuhan Yang Maha kuasa dan dapat dijadikan sebagai sumber pembelajaran.

Kedua, Nilai Menjaga Psikologis dan Kesehatan, yaitu tradisi lokal upacara mitoni ini juga bapak ibu dapat dimaknai sebagai ketidakstabilan emosi bagi seorang ibu yang sedang hamil pada usia kandungan tujuh bulan. Pada umumnya, seorang ibu akan muncul

${ }^{17}$ Istilah mitoni itu sendiri berasal dari kata 'pitu' yang artinya 'tujuh'. Masyarakat mengedepankan nilai-nilai etika tradisi mitoni, merupakan proses persiapan dalam menghadapi proses kelahiran bayi sehingga harus ada selamatan kehamilan yang disebut dengan istilah sedekah wulan atau candraning bobot 
rasa takut pada trimester ketiga ini, ibu mungkin merasa cemas dengan kehidupan bayi dan kehidupannya sendiri. Depresi ringan mulai muncul dan itu merupakan hal umum yang terjadi pada ibu hamil di trimester ini. Maka seorang ayah harus memahami hal tersebut untuk menjaga stabilitas emosional ibu. Berarti dari sini dapat kita ambil pelajaran bahwa kita harus menjaga psikologis dan kesehatan terutama bagi ibu-ibu hamil.

Ketiga, Nilai Hubungan Sosial Kemasyarakatan, yaitu Dilihat dari aspek sosial, upacara Mitoni (tujuh bulanan) yang bapak ibu lakuakan ini memiliki nilai sosial yang tinggi. Acara ini dapat mempersatukan kerukunan, kerjasama, saling membantu antar masyarakat, melestarikan nilai gotong royong dan menghilangkan sifat individualisme. Karena pada hakikatnya manusia itu adalah makhluk sosial yang tidak dapat hidup sendiri, mereka akan saling bergantung satu sama lain dan membutuhkan pertolongan dan bantuan dari orang lain. Disinilah kerukunan antar tetangga akan tercipta. Dengan demikian melalui tradisi ini akan terpeliharanya integritas sosial dikalangan komunitas dan kerabat, serta dapat membangun nilai-nilai kebersamaan atau nilai-nilai gotong royong. Sebagai suatu bentuk proses akomodasi sosial yang efektif, baik dilihat dari kepentingan keluarga maupun masyarakat.

\section{Tradisi Tahlilan (selamatan orang yang telah meninggal)}

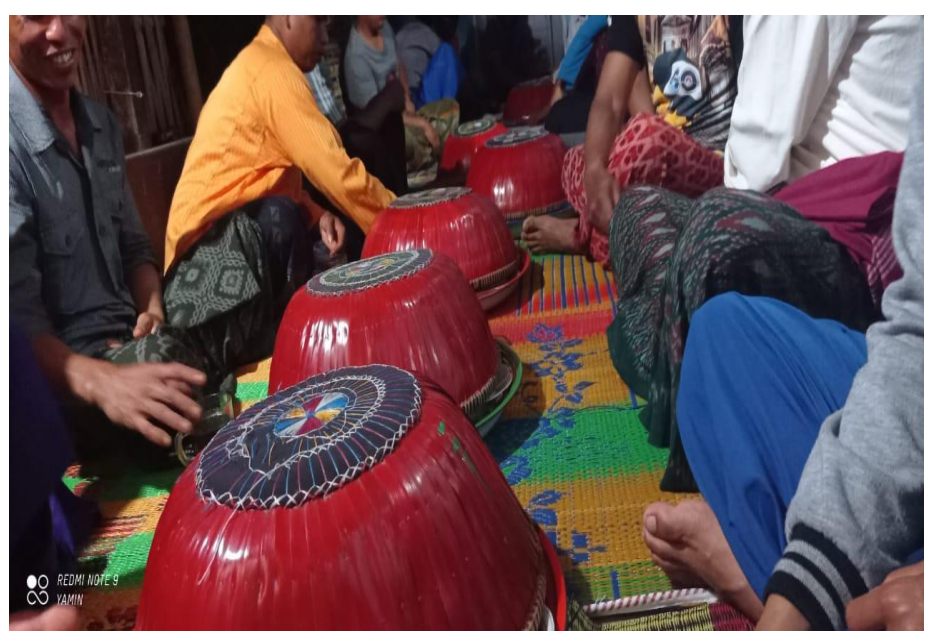

Tradisi Tahlilan ini dilakukan setiap ada hajat masyarakat, terlebih ada orang yang meninggal dunia dan dilaksanakan oleh keluarga yang ditinggalkan. Khusus untuk tahlilan orang yang meninggal dunia ada waktu dan aturan

pelaksanaannya. Adapun waktu pelaksanaannya bertepatan dengan kematian yaitu dengan membaca tahlil selama sembilan malam. tahlilan malam ke tiga setelah kematian di sebut nelu (Tiga), tujuh hari setelah kematian disebut mituq (Tujuh), sembilan hari 
kematian disebut nyiwaq (sembilan), empat puluh hari disebut metang dase (empat puluh), seratus hari kematian disebut nyatus (seratus).

Dalam tradisi tahlilan ini ada beberapa nilai-nilai yang terkandung untuk dijadikan penguatan dalam mengembangkan kehidupan sosial kemasyarakatan yang religius dan diwariskan kepada generasi muda di antaranya: Nilai sedekah, ukhwah islamiyah, tolong menolong, solidaritas, akidah, syari'ah, dan akhlak.

Dalam kegiatan sosialisasi/ ceramah dan diskusi kami menjelaskan satu persatu kepada pemuda dan masyarakat tentang nilai-nilai yang ada dalam tradisi tahlilan. Pertama, Nilai Sedekah yaitu Makanan dan minuman yang dihidangkan bagian dari berbagi kepada sesama. Sajian dalam pelaksanaan selamatan kematian itu tidak saja harus berupa makanan, tetapi bisa juga berupa lainnya. Hal yang demikian itu tergantung pada kadar kemampuan dari pihak keluarga bapak ibu masing-masing yang melakukannya. Bahkan tidak menutup suatu kemungkinan bisa hanya berupa minuman (air), untuk sebatas menghilangkan rasa haus selama berada di perjalanan di samping tidak begitu membebani atau menyibukkan keluarga si mayat. Dalam agama Islam itu yang disebut dengan sedekah. Sedekah merupakan sebaik-baiknya pintu kebajikan. Selamatan yang dilakukan di saat kematian merupakan suatu bentuk kebajikan yang dianjurkan oleh Islam. Kebaikan bapak ibu semoga yang diharapkan pahala dari padanya akan sampai kepada si almarhum.

Kedua, Nilai Ukhwah Islamiyah dan Tolong Menolong yaitu tradisi selamatan kematian yang bapak ibu lakukan dapat memberikan kesempatan berkumpulnya sekelompok orang berdoa bersama, makan bersama secara sederhana, merupakan suatu sikap sosial yang mempunyai makna turut berduka cita terhadap keluarga si mayat atas musibah yang menimpanya, yaitu meninggalnya salah seorang anggota keluarganya. Di samping itu, juga barmakna mengadakan silaturrahmi serta memupuk ikatan persaudaraan antara mereka. Perkumpulan berduka cita yang disertai dengan bertahlil bersama itu merupakan ajaran agama Islam, ada nilai-nilai persaudaraan. Dan melakukan kegiatan perkumpulan di rumah si mayat tidak lain untuk mengadakan doa bersama untuk dihadiahkan kepada si mayat atau setidaknya dengan suatu harapan pahala kebaikan yang dilakukan orang banyak itu mampu menghapus siksa yang akan menimpa si mayat, atau 
setidaknya bisa mengurangi siksaannya. Menghadiahkan do'a kepada si mayat dengan keyakini yang tinggi insya Allah akan sampai kepadanya dan itu juga diajarkan oleh Rasulullah SAW.

Ketiga, Nilai Solidaritas yaitu kegiatan tahlilan atau selamaten yang bapak ibu lakukan itu merupakan suatu ciri khas dalam menghadapi keluarga yang berduka cita adalah bertakziah dengan membawa bawaan untuk diberikan kepada keluarga si mayat, dengan harapan dapat membantu meringankan penderitaan mereka selama waktu berduka cita. Bentuk bawaan menurut kebiasaan dapat berupa beras, gula, uang dan lain sebagainya. Tradisi nyumbang itu merupakan wujud solidaritas seorang anggota masyarakat terhadap saudara, anggota, rekan kerja atau anggota masyarakat lainnya yang sedang memiliki hajatan, itu disebut dengan nilai solidaritas atau nilai kemanusiaan.

Keempat, Nilai Akidah, yaitu pada intinya tahlilan yang bapak ibu lakukan itu adalah sebuah ritual Islami yang mengandung nilai-nilai filosofis keagamaan. Nilai-nilai filosofis keagamaan, bagi orang Islam yang mengikuti tahlilan, mengucapkannya di mulut dan memaknainya secara mendalam di hati kemudian menerapkannya dalam kehidupan bermasyarakat. Maka kemudian pemaknaan tersebut mendasari perilaku mereka dalam bermasyarakat. Seseorang tadi akan menjaga hubungannya dengan Allah dan juga menjaga hubungan dengan sesamanya. Seseorang tadi tidak akan melakukan hal-hal yang tidak diridai oleh Allah, misalnya ia sering mencaci maki sesamanya. Oleh karena itu, secara tidak langsung telah memutuskan hubungannya dengan Allah dan secara langsung memutuskan hubungannya dengan sesamanya. Hal demikian merupakan salah satu nilai yang mendasari masyarakat untuk lebih menghormati keyakinan beragama orang lain sehingga kerukunan antarumat beragama dapat tercipta.

Kelima, Nilai Syari'ah, yaitu Berdoa bersama yang bapak ibu lakukan pada saat ada kematian adalah sesuatu yang telah disyariatkan sebagai salah satu jalan untuk mengabdi dan memohon pertolongan serta berkomunikasi dengan Allah Swt. Membaca surah Yaasiiiiin dan membaca surah-surah lain adalah dua macam ritual keagamaan yang melengkapi tradisi tahlilan. Al-Qur'an adalah kitab agama Islam yang memuat berbagai aspek kehidupan ummat manusia, baik dalam hal akidah, ibadah, hukum, hikmah, sastra, akhlak, kisah-kisah, nasihat-nasihat, ilmu pengetahuan, berita, hidayah, dan pijakan 
argumentasi. Al-Qur'an adalah dasar-dasar risalah tauhid, kasih sayang yang disandarkan pada hubungan ummat manusia, dan sebagai penuntun yang jelas untuk menggapai sebuah kebahagiaan dan kesejahteraan hidup, itu yang sebut dengan nilai-nilai syari'ah. Abul A'la Maududi mengatakan Syariah merupakan cara dan jalan yang ditempuh dalam pengabdian kepada Allah SWT. ${ }^{18}$

Keenam, Nilai Akhlak yaitu Bapak Ibu yang berbahagia, kehadiran agama Islam yang dibawa Nabi Muhammad Saw, diyakini dapat menjamin terwujudnya kehidupan manusia sejahtera lahir dan batin. Di dalamnya terdapat berbagai petunjuk tentang bagaimana seharusnya manusia itu menyikapi hidup dan kehidupan ini secara lebih bermakna. Tradisi tahlilan yang bapak ibu lestarikan merupakan cerminan akhlak kita kepada orang meninggal dunia. Nikmat kubur dan siksa kubur si mayit dapatkan adalah imbalan dari perbuatan sewaktu di dunia. Itu menyangkut dengan bagaimana hubungan almarhum dengan Allah dan bagaimana juga hubungan almarhum dengan sesamanya. Jika selama hidupnya ia menjaga hubungan baik dengan makhluk dan Khaliknya maka ia mendapatkan nikmat kubur, sebaliknya jika selama hidupnya ia zalim kepada makhluk dan Khaliknya maka ia mendapat siksa kubur.

\section{Nilai-Nilai Kearifan Lokal dalam Mengembangkan Kehidupan Sosial Religius di Dusun Senganton}

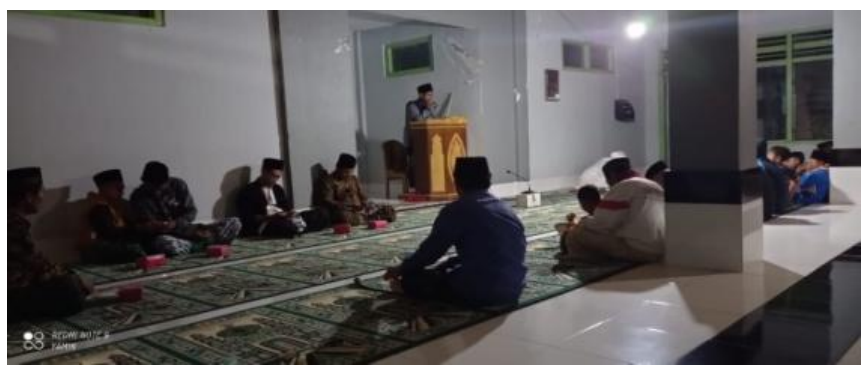

Setelah melakukan sosialisasi atau ceramah menjelaskan tentang nilai-nilai yang ada dalam tradisi-tradisi di Dusun Senganton, para pemuda dan masyarakat merespon dengan baik dan sebagian baru menyadiri bahwa tradisi-tradisi yang selama ini dipraktikkan mengandung nilai-nilai dalam membentuk karakter dan mengembangkan kehidupan sosial yang baik dan religius, yaitu Tradisi upacara mitoni:nilai religi (spiritual), pendidikan,

\footnotetext{
${ }^{18}$ Abul A’la Maududi,” ” Dasar-Dasar Islam “(Bandung: Pustaka, 1984), 98.
} 
menjaga psikologis dan kesehatan, hubungan sosial kemasyarakatan; Tradisi tahlilan: nilai sedekah, ukhwah islamiyah, tolong menolong, solidaritas, akidah, syari'ah, dan akhlak.

Nilai-nilai yang ada dalam tradisi upacara mitoni dan tahlilan di Dusun Senganton tersebut bisa dijadikan sebagai salah satu upaya dan solusi alternatif bagi pelaksanaan penguatan mengembangkan kehidupan sosial dan religius dan pendidikan karakter yang sesuai dengan keunggulan lokal yang dimiliki masing-masing daerah dalam mencegah dan mengurangi pergeseran nilai-nilai religius kemanusiaan akibat adanya arus globalisasi. Hal ini sejalan dengan fungsi pendidikan nasional yang dijelaskan dalam UUD 1945 alenia ke 4 yaitu mengembangkan kemampuan dan membentuk watak serta peradaban bangsa yang bermartabat dalam rangka mencerdaskan kehidupan bangsa, dan untuk mengembangkan potensi pemuda agar menjadi manusia-manusia yang beriman dan bertakwa kepada Tuhan Yang Maha Esa, Berakhlak, tolong menolong dan lain-lain.

Melalui pengkajian, menjelaskan dan penguatan nilai-nilai kearifan lokal secara terus-menerus, mengembangan komunitas kehidupan sosial religiusdapat dilakukan dengan lebih efektif dan sesuai dengan karakter masyarakat sasaran. Oleh karena itu, penting bagi generasi muda seperti Dusun Senganton,untuk memahami apa yang menjadi akar budaya di masyarakat masing-masing. Tujuannya agar komunitas kehidupan di masyarakat bisa berkembang sesuai dengan akar dan karakteristiknya sesuai dengan perkembangan zaman. Kearifan lokal dapat memiliki sifat antarbudaya dan antaretnik yang ada. Jika sifat-sifat tersebut sudah menjadi satu, maka kearifan lokal tersebut dapat membentuk tingkat tatanan nilai yang baru yakni nilai budaya yang bersifat nasional bahkan internasional.

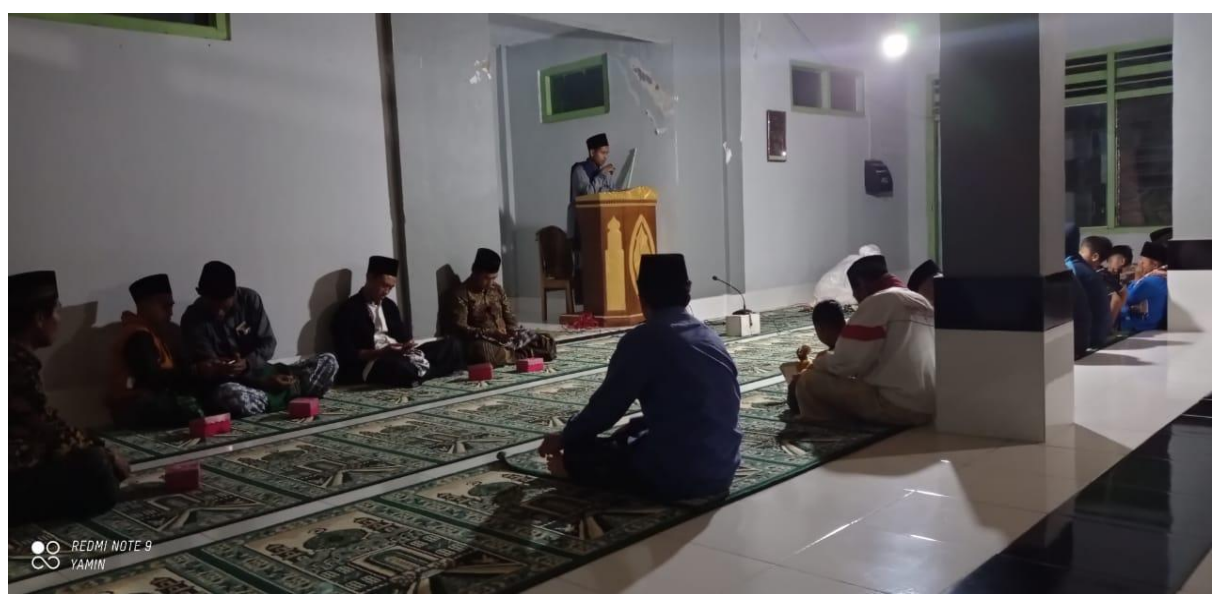

Gambar 1. sosialisasi nilai-nilai kearifan lokal 


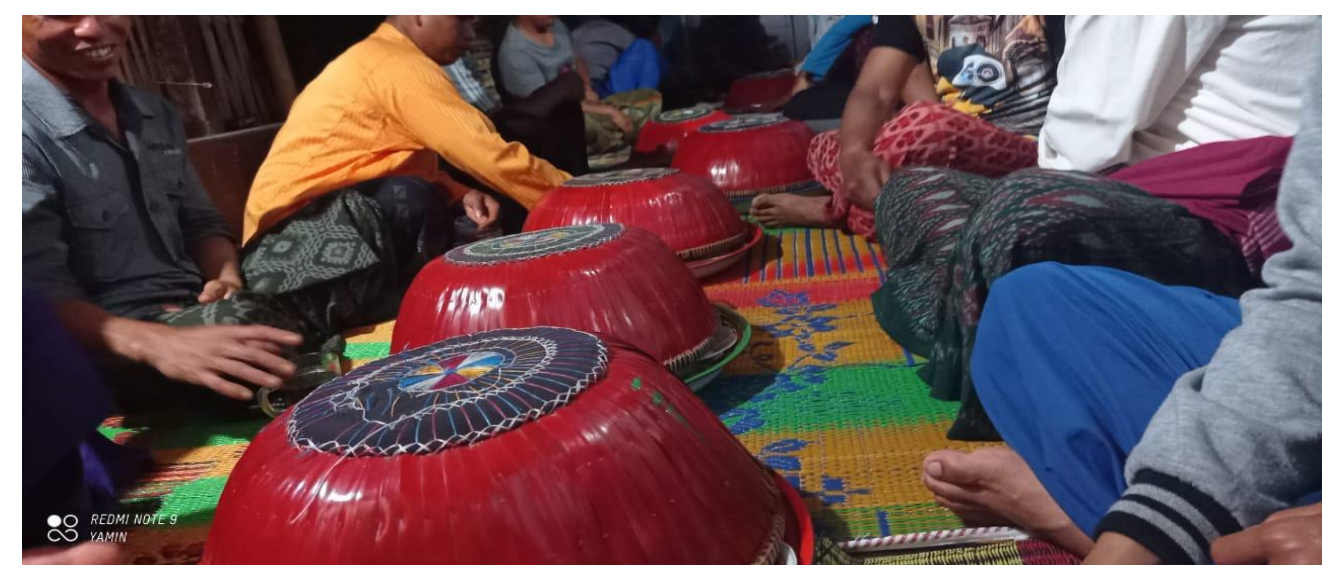

Gambar 2. Acara tahlilan bersama warga dusun senganton

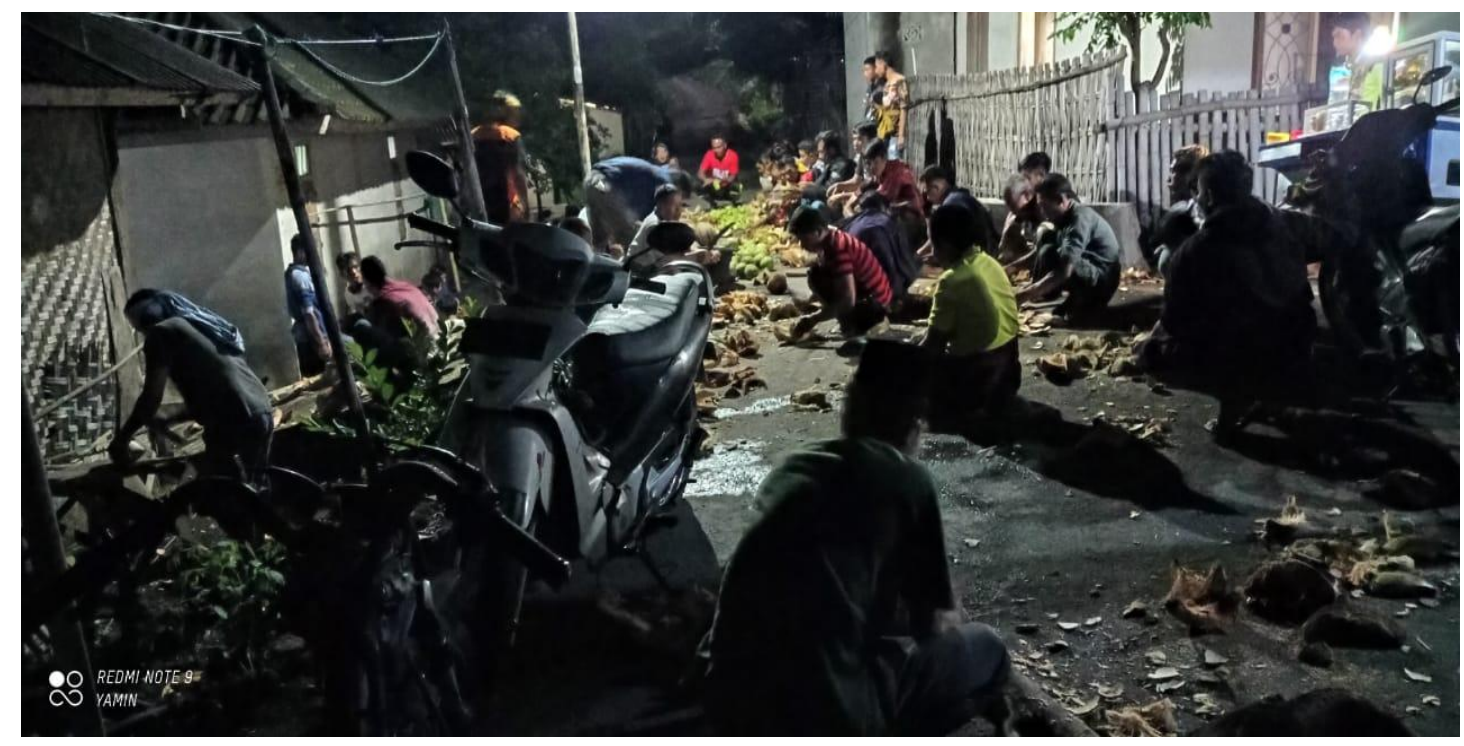

Gambar 3. Acara mitoni

Pada bagian ini uraikanlah bagaimana kegiatan dilakukan untuk mencapai tujuan. Jelaskan indikator tercapainya tujuan dan tolak ukur yang digunakan untuk menyatakan keberhasilan dari kegiatan pengabdian yang telah dilakukan. Ungkapkan keunggulan dan kelemahan luaran atau fokus utama kegiatan apabila dilihat kesesuaiannya dengan kondisi masyarakat di lokasi kegiatan. Jelaskan juga tingkat kesulitan pelaksanaan kegiatan maupun produksi barang dan peluang pengembangannya kedepan. Artikel dapat diperkuat dengan dokumentasi yang relevan terkait jasa atau barang sebagai luaran, atau 
fokus utama kegiatan. Dokumentasi dapat berupa gambar proses penerapan atau pelaksanaan, gambar prototype produk, tabel, grafik, dan sebagainya.

\section{KESIMPULAN}

Berdasarkan Penjelasan sebelumnya dapat disimpulkan bahwa para pemuda dan masyarakat Dusun Senganton Desa Beririjarak sebagian baru menyadari bahwa tradisi-tradisi yang selama ini dipraktikkan mengandung sarat dengan nilai-nilai sosial dan keagamaan seperti tradisi upacara mitoni sarat dengan nilai-nilai religi (spiritual), pendidikan, menjaga psikologis dan kesehatan, hubungan sosial kemasyarakatan; dan tradisi tahlilan sarat dengan nilai- nilai sedekah, ukhwah islamiyah, tolong menolong, solidaritas, akidah, syari'ah, dan akhlak. Tradisi-tradisi di Dusun Senganton tersebut merupakan bagian dari budi pekerti yang memiliki makna filosofis dalam kehidupan dan merupakan warisan masa lalu yang berasal dari leluhur serta akulturasi budaya lokal dengan Islam..

Dengan demikian melalui pengkajian serta penguatan nilai-nilai kearifan lokal dapat membangun karakter anak bangsa dan mengembangkan kehidupan sosial religius dengan mengedepankan kearifan lokal yang mengandung nilai- nilai yang relevan dan berguna bagi masyarakat. Namun hal tersebut tidak bisa lepas dari peran masyarakat yang berusaha secara optimaldalam upaya pengembangan kearifan lokal sebagai sumber pembelajaran dan juga memerlukan adanya pengertian, pemahaman, kesadaran, kerja sama, dan partisipasi seluruh elemen masyarakat.

\section{UCAPAN TERIMA KASIH}

Ucapn terima kasih yang paling utama adalaha rasa syukur kepada Allah SWT, atas limpahan rahmat dan karunia-Nya sehingga penulis dapat menyusun jurnal ini. Selanjutnya kami haturkan ucapan terima kasih seiring do'a dan harapan jazakumullah ahsanal jaza kepada semua pihak yang telah membantu terselenggaranya jurnal ini. Ucapan terima kasih ini kami sampaikan kepada:

1. Prof. Dr. H Lukman Al-Hakim, MM. Selaku ketua STAI Darul Kamal NW Kembang Kerang Lombok Timur, yang telah banyak memberikan pengetahuan dan pengalaman.

2. Muh. Tarmizi Tahir M.A. Selaku dosen pembimbing lapangan(DPL), yang telah banyak memberikan pengarahan dan pengalaman berharga buat kami.

3. Segenap penyelenggara kegiataan KKP PAR STAI DARUL KAMAL NW KEMBANG KERANG, yaitu LP2M (Lembaga Penelitian Dan Pengapdian Pada Masyarakat) yang telah memberikan kesempatan untuk melaksanakan kegiatan KKP (Kuliah Kerja Pasrtisipatif).

4. Lalu Pauzi, selaku kepala desa beririjarak, Dan semua jajaran pemerintahan yang ada di desa beririjarak.

5. Supiandi S.Pd selaku pelaksana kewilayahan sementara dusun senganton, yang sangat banyak membantu proses kegiatan KKP di desa beririjarak.

6. Semua Elemen Masyarakat( Tokoh Agama, Tokoh Masyarakat, Sesepuh Dan semua pihak yang membantu suksesnya pelaksana KKP STAI Darul Kamal NW Kembang Kerang di Desa Beririjarak.

Akhirnya jurnal yang kami buat dapat tersusun dengan baik, semoga jurnal ini bisa bermanfaat bagi para pembaca. 


\section{DAFTAR PUSTAKA}

Abul A'la Maududi,(1984) "Dasar-Dasar Islam",Bandung:Pustaka

Hasil Diskusi Bersama Muh.Tarmizi Tahir Selaku Pembimbing Lapangan (18Pebruari2021)

Hasil diskusi bersama Kepala Desa (18Pebruari2021), Lihat Juga Dokumen Desa Beririjarak

Koentjaraningrat,(2009)" Pengantar I/mu Antropologi",Jakarta:AksaraBaru

Lihat Dokumen Desa Beririjarak tentang profil Desa.

Syam,F, RenunganBJ.Habibie(2009). Membangun Peradaban Indonesia, Jakarta:GemaInsani

Yunus,Rasid,(2014).Nilai-nilai Kearifan Lokal (LocalGenius) sebagai Penguat Karakter

Bangsa:Studi Empiris tentang Huyula,(Yogyakarta:Deepublish 